\title{
Piezoelectric Thin Films for Microtransducer
}

\author{
Soo Young Jung ${ }^{1,2}$ and Seung-Hyub Baek ${ }^{1, \dagger}$
}

${ }^{1}$ Center for Electronic Materials, Post-Silicon Institute, Korea Institute of Science and Technology, Seoul 02792, Korea

${ }^{2}$ Department of Materials Science and Engineering, Seoul National University, Seoul 08826, Korea

\section{마이크로 트랜스듀서를 위한 압전 박막 소재 기술 동향}

\author{
정수영 1,2 , 백승협, $†$ \\ 1한국과학기술연구원, 차세대반도체연구소 전자재료연구단, ${ }^{2}$ 서울대학교 재료공학부
}

(Received March 5, 2019; Accepted March 22, 2019)

\begin{abstract}
s
Piezoelectric materials can directly convert mechanical energy to electrical one, and vice versa. Research on piezoelectric materials and devices has a long history, and now many relevant products are available in a wide range of applications such as medical, military, industrial, home appliance, and mobile electronics. One of the major research trends now is not only to further improve the physical properties of the piezoelectric materials, but also to reduce the size of the piezoelectric devices. This review focuses on the development of piezoelectric thin films that can enhance the performance of microtransducers.
\end{abstract}

Keywords: $p-M U T$, piezoelectric thin film, MEMS, transducer

\section{1. 서론}

초음파는 인간이 들을 수 있는 가청주파수(20 Hz 20 $\mathrm{kHz}$ ) 보다 높은 주파수를 갖고 있는 고주파 음압(sound pressure)을 의미한다. 주파수가 높을수록 파장이 짧아 지므로 회절 현상이 줄어들고 직진성이 강해지며, 기계적 성질이 다른 계면에서 반사하는 경향을 갖는다(Fig. 1.). 초음파 기술은 크게 두 가지로 나눌 수 있다. 첫째는 빛을
이용할 수 없는 공간에서 초음파의 진동을 이용하여 “볼" 수 있는 이미징 기술이다. 예를 들어, 의료용 초음파 기

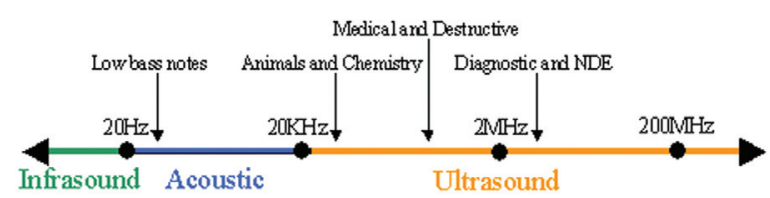

Fig. 1. 초음파 주파수 영역 및 응용분야 
술은 초음파를 인체 내부로 주입하고, 반사되는 파를 수 신 및 분석하여 각종 인체 기관의 위치, 거리, 모양, 병리 학적 손상 등을 이미지화하여 환자 장기의 건강상태를 진 단할 수 있게 한다. 또한, 건물의 기둥이나 파이프 내부 에 발생하는 결함을 찾아 큰 사고를 미연에 방지하고 구 조물의 수명을 예측하는 산업용 비파괴 검사 용도로도 쓰 이고 있다. 이외에도 빛이 닿지 않는 심해의 물고기 떼나, 잠수함, 선박 등을 탐지할 수 있는 목적으로도 사용되고 있다. 둘째는 초음파의 에너지를 이용하여 대상의 상태를 물리적, 화학적으로 변화시키는 제어 기술이다. 체내의 담석이나 이물질을 초음파를 이용하여 파쇄할 수 있고, 수술 없이 종양조직을 제거할 수 있다. 뇌에 초음파 진동 자극을 가하여 뇌졸중 후유증으로 발생한 신체 부분 마비 현상을 치료하는 경우도 있다. 또한 강력한 초음파 진동 을 이용해 수백 만개의 미세 공동을 붕괴시켜 이때 나오 는 에너지를 이용해 물속의 오염물질 분해가 가능하기 때 문에, 초음파 세척 및 살균 등의 목적에도 사용된다. 이 외에도 초음파를 이용한 정보 송수신, 지문인식, 입자 수 송 및 위치제어 등 많은 응용분야가 있다. ${ }^{1-5)}$

초음파 트랜스듀서는 초음파를 발생시키고 반사된 초 음파를 감지할 수 있는 소자를 말한다. 현재 대부분의 초 음파 트랜스듀서는 압전(piezoelectric) 물질을 사용하고 있다. 압전 소재는 전기적 에너지를 기계적 에너지로, 혹 은 그 반대 방향으로 에너지 전환을 가능케 하는 특성을 갖고 있다. 압전 소재의 종류, 성능, 형태 및 구동 방식 등 에 의해 초음파 트랜스듀서의 구조와 성능이 결정된다. 압전 소자의 응용범위와 성능을 획기적으로 개선시키기
위해 많은 노력이 진행중이며, 특히 새로운 압전 소재 개 발과 이차원 어레이 구성이 가능한 마이크로트랜스듀서 에 대한 연구가 두드러진다. 따라서, 본 보고에서는 마이 크로 트랜스듀서에 적합한 압전 박막 소재의 개발 현황에 대해 다루었으며 향후 연구 전망에 대해 논의 하였다.

\section{2. 본문}

\section{1 초음파 트랜스듀서 구조}

현재 사용되고 있는 초음파 트랜스듀서는 Fig. 2A. 와 같은 구조를 갖고 있다. 벌크 형태의 압전 단결정 또는 소 결체를 가공하고, 상하부에 금속 전극을 연결한 커패시터 구조를 기본으로 한다. 초음파가 발생하는 윗면에는 매칭 (matching) 레이어가, 반대쪽 아랫면에는 백킹 (backing) 레이어가 존재한다. 초음파는 외부에서 압전 소재에 교류전압을 가했을 때 발생하므로 기본적으로 상 부와 하부 양방향으로 초음파가 발생하게 된다. 반사에 의한 손실을 최소화 하고 관찰대상에 초음파를 효율적으 로 주입하기 위해서, 윗면에는 관찰대상과 기계적 임피던 스가 유사한 매칭 레이어가 필요하다. 의료용 초음파의 경우 폴리머 계열 소재를 사용한다. 반면, 아랫면에는 아 래 방향으로 발생한 초음파가 하우징에 반사되어 수신될 수 있기 때문에 초음파를 흡수할 수 있는 백킹 레이어가 존재한다. 이러한 소자 구조에서 압전소재는 $\mathrm{d}_{33}$ 모드로 구동하여 초음파를 발생 및 생성하게 된다. $\mathrm{d}_{33}$ 모드는 전 기장을 가하는 방향과 평행한 방향으로 압전 소재가 팽창 수축을 반복하며 초음파를 생성하는 것을 말한다. 이런
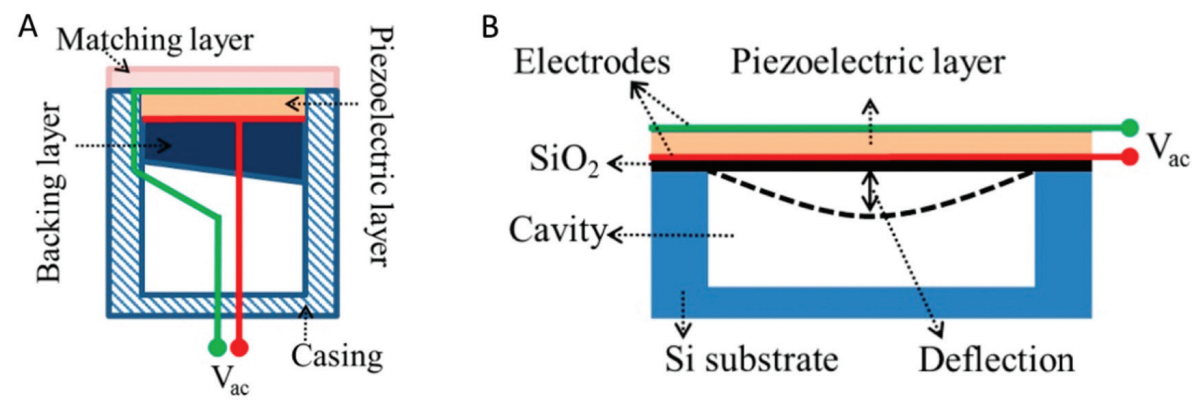

Fig. 2. 초음파 트랜스듀서의 구조, A. 벌크 압전소재를 이용한 $\mathrm{d}_{33}$ 모드 구동 방식, B. 압전박막 소재를 이용한 $\mathrm{d}_{31}$ 모드 구동방식 (마이크로 트 랜스듀서 $)^{11}$ 


\section{특 집 ㅁㅃ 정수영, 백승협}

구조에서 압전소재는 박막 형태보다는 벌크 형태가 적당 하다. 박막은 두께가 얇기 때문에 외부에서 가한 전압에 의해 실제로 두께방향으로 수축 팽창하는 변위의 크기가 낮을 수 밖에 없고, 이는 충분한 에너지를 갖는 초음파를 발생시키기 어렵기 때문이다.

이와 같은 벌크 압전소재 기반의 초음파 트랜스듀서의 문제점은 크게 두 가지다. 첫째, 주파수 제어가 힘들다. $\mathrm{d}_{33}$ 모드에서는 압전소재의 공명주파수가 압전 소재의 두 께 및 폭에 의해 결정된다. ${ }^{6-10)}$ 높은 주파수의 트랜스듀 서 제작을 위해서는 좁고 긴 형태의 어레이 셀이 필요한 데 벌크 절삭 가공 방식으로는 한계가 있으며, 수율이 낮 은 단점이 있다. 둘째, 배선이 어려워 이차원 어레이를 구 현하기 힘들다. 삼차원 초음파 이미지를 얻기 위해서는 초음파 빔의 방향과 초첨거리 등을 제어할 수 있는 이차 원 트랜스듀서 어레이가 필요하다. 이차원 어레이의 각 셀에서 서로 다른 위상을 갖는 전기신호를 보내면 발생하 는 초음파는 간섭을 일으켜 초음파 빔(beam) 을 형성할 수 있고 방향 및 초점거리 제어가 가능하다. 벌크 소재를 이용한 $\mathrm{d}_{33}$ 모드 구동시 이차원 어레이에 있는 각각의 초 음파 셀에 전극을 독립적으로 연결해야 하는데 어레이가 커질수록, 구동 주파수가 높아질수록 배선 문제가 심각한 공정문제로 떠오르게 된다. 또한 배선이 수작업으로 이루 어지기 때문에 공정 단가가 높고 생산속도가 현저하게 떨 어지는 단점이 있다.

따라서 이러한 문제를 해결하기 위해서는 MEMS 공정 을 이용한 압전 박막 기반의 마이크로 트랜스듀서 (piezoelectric micromachined untrasound transducer, p-MUT) 제작이 필요하다(Fig. 2B.).
$\mathrm{p}-\mathrm{MUT}$ 은 구조가 간단하여 공정이 쉬운 장점이 있다. 일반적으로 SOI 기판을 사용하여 앞면에 상하부 전극이 연결된 압전 박막이 위치하고, 뒷면의 $\mathrm{Si}$ 기판을 $\mathrm{DRIE}$ 등의 공정으로 에칭하여 멤브레인 구조를 만든다. 이러한 구조에서 압전 멤브레인은 $\mathrm{d}_{31}{ }^{11,12)}$ 모드로 구동하게 된다. 즉, 상하부 전극에 가해지는 전기장과 수직한 방향으로 압전 박막이 수축 및 팽창을 하게 되고, 압전 박막 아래쪽 의 실리콘 층이 패시브 층으로 작용하여 멤브레인 전체가 위 아래로 벤딩하는 원리로 초음파가 아래쪽으로 발생하 게 된다. 이때 뒷면의 $\mathrm{DRIE}^{6,7,9,13,14)}$ 로 에칭된 부분은 초 음파가 아래쪽 방향으로 잘 전파되도록 가이드 하는 확성 기 역할을 한다. 압전 박막 기반의 $\mathrm{d}_{31}$ 모드를 이용하는 $\mathrm{p}-\mathrm{MUT}$ 소자는 기존의 벌크형 소자가 갖고 있는 문제를 해결할 수 있다. Microfabrication 공정을 이용하므로 배선 공정에서 발생하는 문제를 해결할 수 있으며, 실리 콘 기판의 크기에 따라 대면적화가 가능하고, 어레이 개 수 증가 및 셀 집적화가 용이하여, 생산속도 및 경제성 문 제에서 매우 유리하다. 또한, 초음파 어레이 셀의 사이즈 및 패시브 층의 두께 등을 제어하면 공진 주파수를 용이 하게 제어할 수 있기 때문에 보다 광범위한 응용분야에 적용이 가능하다.

이러한 $\mathrm{p}-\mathrm{MUT}$ 소자에서 가장 중요한 것은 압전 박막 의 물성이다. 압전 물성이 우수할수록 작은 전압에서도 높은 강도의 초음파가 발생하며, 미세한 반사파도 쉽게 감지 할 수 있다. $\mathrm{PVDF}^{15)}, \mathrm{AlN}^{13,16)}, \mathrm{ZnO}^{17)}$ 등과 같은 압 전 소재는 증착이 용이한 반면 압전 성능이 $\mathrm{PZT}^{18,19)}$ 등과 같은 페로브스카이트 산화물에 비해 현저히 떨어진다. 따 라서, 많은 연구그룹에서 PZT, PMN-PT 등과 같이 압

Table 1. 압전 소재의 물성과 압전 마이크로 트랜스듀서 소자 특성과의 관계

\begin{tabular}{c|c}
\hline Physical Parameters & Effect \\
\hline High coupling coefficient & High band width \\
\hline High dielectric constant & Low electrical impedance (coaxial : Ze $=50 \Omega)$ \\
\hline Low dielectric constant & High piezoelectric voltage \\
\hline High piezoelectric coefficient & Large strain \\
\hline Low elastic stiffness & Acoustic impedance matching (water Zm=20Mrayl) \\
\hline High mechanical and electrical Q for materials & High resonance frequency \\
\hline High speed of sound & Hosses
\end{tabular}


전 성능이 매우 우수한 $\mathrm{Pb}$ 기반의 페로브스카이트 산화 물을 이용한 박막 증착 및 소자 개발에 대한 연구를 활발 히 진행하고 있다.

\section{$2.2 \mathrm{p}-\mathrm{MUT}$ 을 위한 압전 박막 소재}

압전 소재의 물성과 $\mathrm{p}-\mathrm{MUT}$ 소자의 성능과의 관계가 Table 1 에 요약되어 있다. 초음파 트랜스듀서의 응용처 에 따라 소재의 종류, 형태, 증착 방법 등이 고려되어야 한다.

\subsection{1 $\mathrm{Pb}(\mathrm{Zr}, \mathrm{Ti}) \mathrm{O}_{3}$}

$\mathrm{Pb}(\mathrm{Zr}, \mathrm{Ti}) \mathrm{O}_{3}(\mathrm{PZT})$ 는 $\mathrm{PbZrO}_{3}$ 와 $\mathrm{PbTiO}_{3}$ 사이의 솔리 드 솔루션을 이루는 물질로 현재 가장 많이 사용되고 있 는 압전 물질이다. $\mathrm{Zr}: \mathrm{Ti}$ 의 비율에 따라 $\mathrm{PZT}$ 의 결정구 조가 바뀌며 각종 물성도 변화한다. 압전성능이 가장 뛰 어난 52/48 조성을 많이 쓰며, 도핑 기술을 이용하여 hard 또는 soft 압전 소재로 물성 제어가 가능한 장점이 있다. PZT 는 스퍼터링, 졸겔법, MOCVD등의 기술로 박 막 증착이 가능하며, 이차 상 생성이 쉽게 일어나지 않아 공정 난이도가 상대적으로 쉽다는 장점이 있다. $\mathrm{PZT}$ 박 막을 이용한 압전 멤스 소자가 이미 상용화 되어 잉크젯 프린터, 자이로 센서등에 쓰이고 있다. ${ }^{1,5,19)}$

금속전극 위에 증착할 경우 다결정 박막이 형성된다.
압전 물성은 소재의 결정구조에서 기인하는 것이므로 결 정방향에 따라 물성이 달라지게 된다. 이러한 이방성 때 문에 압전 소재가 다결정 구조를 가질 경우 압전 물성은 소재가 발휘할 수 있는 최대값과 최저값의 평균 이하 수 준을 가질 수 밖에 없다. 또한 다결정 소재의 경우 각 그 레인의 자발분극이 랜덤한 방향을 갖고 있으므로, 압전 구동을 위해서는 각 그레인의 자발분극을 수직방향으로 정렬하기 위한 폴링(poling) 공정이 반드시 필요하다.

이러한 문제를 해결하기 위해 에피택시 증착 기술이 제 시되었다. 실리콘과 페로브스카이트 산화물은 결정구조 가 매우 다르고, 산화물 증착시에 실리콘 표면에 $\mathrm{SiO}_{2}$ 가 쉽게 생성되기 때문에 에피택시 성장이 용이하지 않다. 따라서, 두 가지 서로 다른 물질을 연결해 줄 수 있는 버 퍼층이 필요한데, 현재 YSZ (Yttria-stabilized zirconium oxide) 와 $\mathrm{CeO}_{2}$ 가 가장 알맞은 버퍼층으로 알려져 있다(Fig. 3.). YSZ는 큐빅구조를 갖고 있으며, $\mathrm{Zr}$ 과 O 사이의 결합력이 $\mathrm{Si}$ 과 O 간의 결합력보다 매우 강하기 때문에 실리콘 표면에 생성된 $\mathrm{SiO}_{2}$ 를 $\mathrm{SiO}$ 로 환원 시킬 수 있고 이때 생성된 $\mathrm{SiO}$ 는 휘발성이 강해 기판에서 증발하게 되어 YSZ 가 실리콘 기판위에서 에피택시 박막 으로 성장이 가능하다. ${ }^{20-26)} \mathrm{CeO}_{2} / \mathrm{YSZ}$ 위에 $\mathrm{La}(\mathrm{Sr}, \mathrm{Mn})$ $\mathrm{O}_{3}$ (LSMO)와 같은 컨덕팅 페로브스카이트 산화물을 에 피택시 박막으로 성장시킬 수 있으며 하부전극으로 사용
A

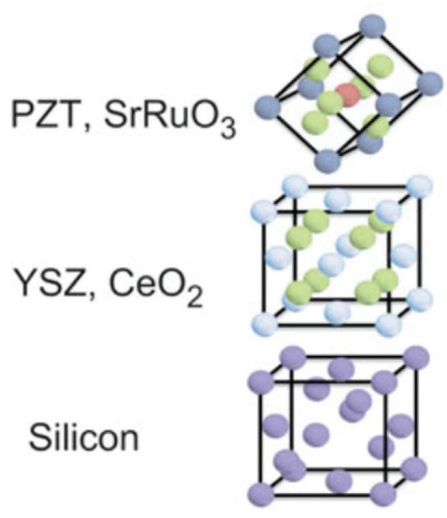

(110)
B

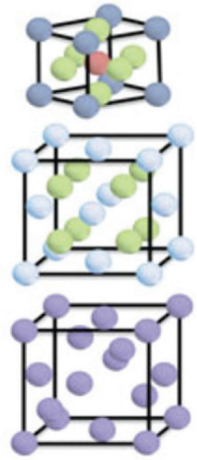

(001)

C

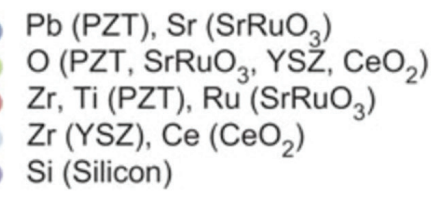

$\mathrm{Pb}(\mathrm{PZT}), \mathrm{Sr}\left(\mathrm{SrRuO}_{3}\right)$ $\mathrm{O}\left(\mathrm{PZT}, \mathrm{SrRuO}_{3}, \mathrm{YSZ}, \mathrm{CeO}_{2}\right)$ $\mathrm{Zr}, \mathrm{Ti}(\mathrm{PZT}), \mathrm{Ru}\left(\mathrm{SrRuO}_{3}\right)$ $\mathrm{Zr}$ (YSZ), $\mathrm{Ce}\left(\mathrm{CeO}_{2}\right)$ Si (Silicon)

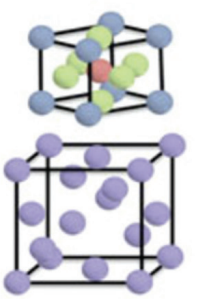

(001)
$\mathrm{PZT}, \mathrm{SrRuO}_{3}$ $\mathrm{SrTiO}_{3}$

\section{Silicon}

Fig. 3. 에피택시 PZT 박막과 Si 기판 및 버퍼층 간의 모식도리 


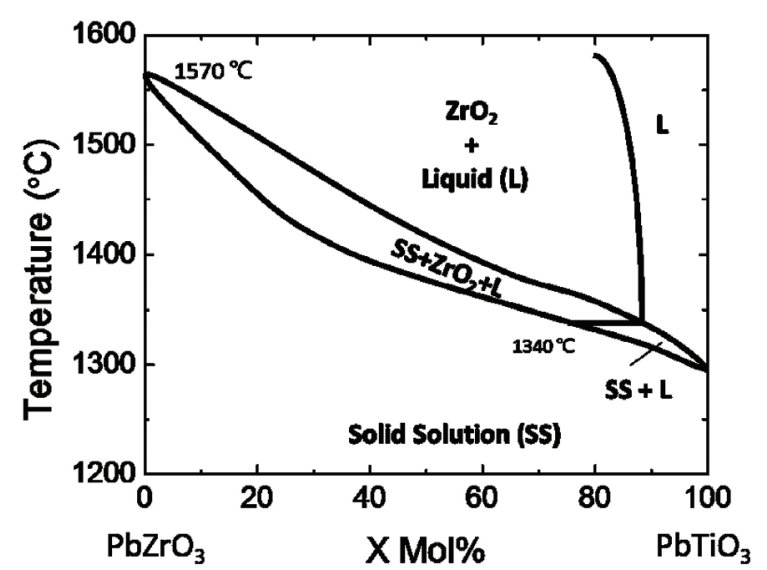

Fig. 4. PZT 상태도 (Incongruent melting) 34 )

할 수 있다. $\mathrm{LSMO}$ 는 $\mathrm{CeO}_{2}$ 과 격자차이가 매우 크지만, in-plane 방향으로 45 도 회전하여 $\mathrm{CeO}_{2}$ 의 대각선 방향 으로 위치하면 격자차이가 $2.2 \%$ 로 감소하여 에피택시 박 막 성장이 가능하다. PZT 는 위와 같은 하부전극/버퍼 층/실리콘 기판 구조 위에 에피택시 성장이 가능하다. 에 피택시 PZT 박막의 배향제어도 가능한 것으로 보고되었 다. 동일한 $\mathrm{CeO}_{2} / \mathrm{YSZ} / \mathrm{Si}$ 구조위에 $\mathrm{SrRuO}_{3}(\mathrm{SRO})$ 물질 을 하부전극으로 성장하면 (110) 배향을 갖는 $\mathrm{SRO}$ 가 증 착되며, 그 위에는 (110) 배향의 PZT를 성장 할 수 있다.
$\mathrm{SRO}$ 는 $\mathrm{LSMO}$ 보다 격자상수가 크기 때문에 $\mathrm{CeO}_{2}$ 와의 격자차이가 더 크다. 이러한 큰 격자 차이를 완화하기 위 해 $\mathrm{SRO}$ 는 (001) 배향이 아닌 (110) 배향으로 성장하게 되 는 것이다. ${ }^{27-29)}$

참고로 브릿지만 또는 초크랄스키와 같은 액상에서 성 장시키는 단결정 성장 기술로는 PZT 단결정 성장이 불가 능하다는 점을 이해하면 에피택시 박막 공정의 중요성을 인식할 수 있다. Fig. 4. 에서 알 수 있듯이 $\mathrm{ZrO}_{2}$ 녹는점 이 매우 높아 incongruent melting ${ }^{30-34)}$ 을 이루기 때문 에 조성제어가 불가능하고 석출된 $\mathrm{ZrO}_{2}$ seed에서 결정이 성장하기 때문에 웨이퍼 크기의 단결정 성장이 어렵다. 반면 기상 증착기술을 이용하면 에피택시 성장기술을 이 용해 쉽게 웨이퍼 스케일의 단결정 PZT 박막 성장이 가 능하다.

\subsection{2 $\mathrm{Pb}(\mathrm{Mg}, \mathrm{Nb}) \mathrm{O}_{3}-\mathrm{PbTiO}_{3}$}

단결정 $\mathrm{Pb}(\mathrm{Mg}, \mathrm{Nb}) \mathrm{O}_{3}-\mathrm{PbTiO}_{3}(\mathrm{PMN}-\mathrm{PT})^{30,35,36)}$ 소 재의 우수성은 1997년 미국 PennState Univ. 에서 처음 보고 되었다(Fig. 5.). PMN-PT는 relaxor 인 $\mathrm{Pb}(\mathrm{Mg}, \mathrm{Nb}) \mathrm{O}_{3}$ 와 ferroelectric 인 $\mathrm{PbTiO}_{3}$ 의 솔리드 솔 루션이다. PZT 소결체의 longitudinal piezoelectric coefficient $\left(\mathrm{d}_{33}\right)$ 와 coupling coefficient $(\mathrm{k})$ 가 각각

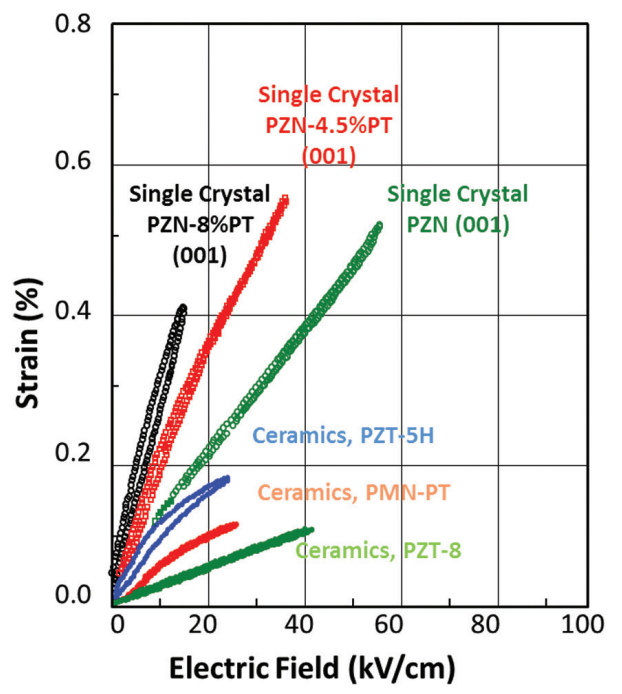

Fig. 5. 완화형 강유전체의 압전 물성 및 비등방성35)
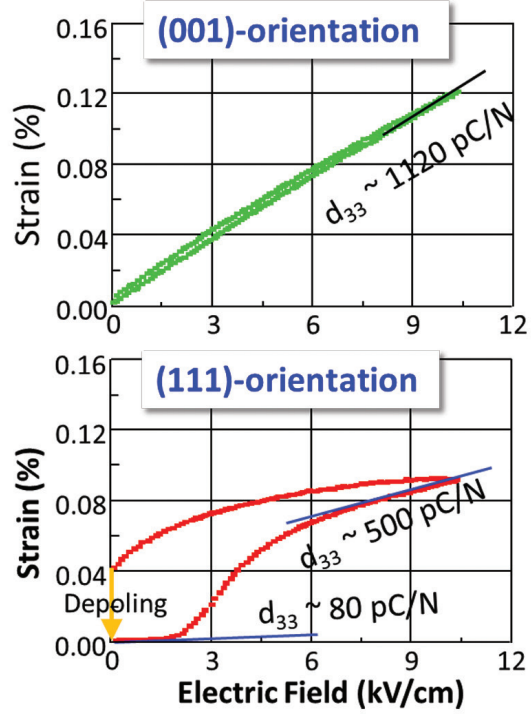


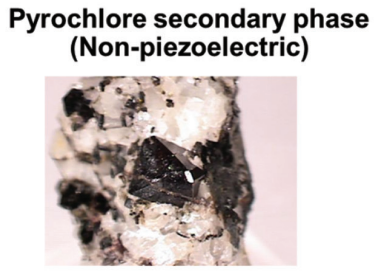

- $\mathrm{Pb}_{2} \mathrm{Nb}_{2} \mathrm{O}_{7}$ - rhombohedral pyrochlore

- $\mathrm{Pb}_{3} \mathrm{Nb}_{4} \mathrm{O}_{13}$ - cubic pyrochlore

- $\mathrm{Pb}_{3} \mathrm{Nb}_{2} \mathrm{O}_{8}$ - tetragonal pyrochlore

Fig. 6. pyrochlore 이차 상 및 이를 억제하기 위한 컬럼바이트 공정

600 (pC/N)와 0.7 인데 반해서, 001 배향의 PMN$\mathrm{PT}$ 단결정은 $>2,000(\mathrm{pC} / \mathrm{N})$ 와 $>0.9$ 를 가지며 $\mathrm{PZT}$ 에 비해 획기적으로 우수한 압전 소재임이 증명되었다. 또 한, 전기장을 가하여 기존 세라믹 소재는 견디지 못하고 깨질 수 밖에 없는 매우 높은 $1.7 \%$ 이상 변형율을 보여주 기도 했다. 이러한 우수한 압전 성능과 큰 변형율을 설명 하기 위해 분극 회전(polarization rotation) 과 전기장 에 의한 상변화(field-induced phase transition)의 개 념이 활발하게 논의 되었다.

$\mathrm{PMN}-\mathrm{PT}$ 는 PZT 와는 다르게 전통적인 기술을 이용 하여 벌크 단결정으로 합성이 가능하다. 주로 브릿지만 (Bridgeman) 법을 사용하는데 제조된 단결정 잉곳 내의 조성 구배로 인해 일부만 사용이 가능하며, 백금 (Platinum) 도가니를 쓰기 때문에 제조 단가가 매우 비 싼 단점이 있다. 특히 조성 구배 문제를 해결하기 위해 Zone-leveling 브릿지만 이나 top-seeded solution growth 법 등이 보고되었다. ${ }^{30,37,38)}$

참고로 비교를 위해 $\mathrm{PMN}-\mathrm{PT}$ 소결체 합성에 대해서 간단히 설명하고자 한다(Fig. 6.). 전통적인 파우더 공정 은 원재료 $\left(\mathrm{PbO}, \mathrm{MgO}, \mathrm{Nb}_{2} \mathrm{O}_{5}, \mathrm{TiO}_{2}\right)$ 를 파우더 형태로 섞 어 하소(calcination)와 소결(sintering) 공정을 수행하 는 것이다. 이와 같은 공정으로는 순수한 페로브스카이트 상을 갖는 $\mathrm{PMN}-\mathrm{PT}$ 소결체 합성이 어려운 것으로 알려 져 있다. 그 이유는 파우더 공정 중에 파이로클로어 (pyrochlore) 이차 상이 쉽게 생성되기 때문이다. $\mathrm{Pb}_{2} \mathrm{Nb}_{2} \mathrm{O}_{7}, \mathrm{~Pb}_{3} \mathrm{Nb}_{4} \mathrm{O}_{13}, \mathrm{~Pb}_{3} \mathrm{Nb}_{2} \mathrm{O}_{8}$ 등과 같이 페로브스카 이트 구조가 아닌 다양한 이차 상이 공정 중에 생성될 수

\section{Columbite Method : two-step process}

For pure perovskite ceramics

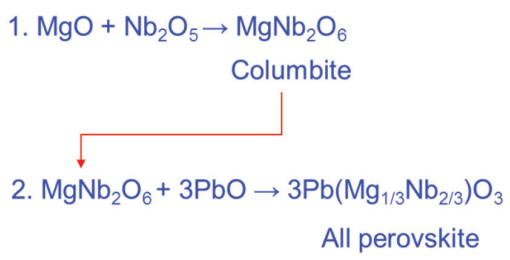

있으며, 열역학적으로 페로브스카이트와 비슷한 안정성 을 갖기 때문에 사라지지 않고 남아있게 된다. 이러한 문 제를 해결하기 위해 컬럼바이트(columbite) 공정이라는 2 단계 공정을 이용한다. 즉, $\mathrm{Nb}_{2} \mathrm{O}_{5}$ 와 $\mathrm{MgO}$ 파우더를 이 용해 먼저 $\mathrm{MgNb}_{2} \mathrm{O}_{6}$ 를 먼저 합성한 후 $\mathrm{PbO}$ 와 $\mathrm{TiO}_{2}$ 파 우더를 추가해 최종적으로 페로브스카이트 PMN-PT 상 을 합성하는 것이다. 사실 $\mathrm{PMN}-\mathrm{PT}$ 소결체의 압전 성능 은 단결정에 비해 매우 떨어지기 때문에 압전 응용을 위 해 PMN-PT 소결체를 제조하는 경우는 매우 드물다. 반 면, 스퍼터링 타겟과 같이 박막 증착을 위한 도구로 사용 되는 경우가 많다.

$\mathrm{PMN}-\mathrm{PT}$ 의 경우 단결정 성장이 PZT 에 비해 용이한 장점이 있지만, 단결정 박막 합성은 매우 어렵다고 알려 져 있다. 1997년 PMN-PT 단결정이 보고된 이후 2011년 에야 벌크 단결정에 비견할 만한 압전 성능을 갖는 에피 택시 박막합성이 보고되었다. ${ }^{39)}$ 에피택시 PMN-PT 박 막을 합성할 때 가장 어려운 점은 stoichiometry를 정확 히 맞추는 일이다. $\mathrm{PMN}-\mathrm{PT}$ 는 다섯가지 원소로 이루어 져 있어 조성이 조금만 벗어나도 순수한 페로브스카이트 상을 갖는 단결정 박막 형성이 불가능하다. 특히, $\mathrm{PbO}$ (녹는점: $888^{\circ} \mathrm{C}$, 끓는점: $1,477{ }^{\circ} \mathrm{C}$ )는 다른 원소에 비해 상대적으로 휘발성이 강하다. 따라서, 조성에 맞은 증착 플럭스가 기판에 도달하더라도 $\mathrm{PbO}$ 가 재증발 $(\mathrm{re}-$ evaporation)하기 때문에 증착된 박막은 $\mathrm{Pb}$ 가 부족해지 게 된다. 이렇게 $\mathrm{Pb}$ 가 부족한 이차 상 환경에서는 pyrochlore 상이 쉽게 형성되는데, 이 이차 상은 압전 성 능이 없으므로 $\mathrm{PMN}-\mathrm{PT}$ 의 단결정 성장을 방해하면서 


\section{특 집 므정수영, 백승협}

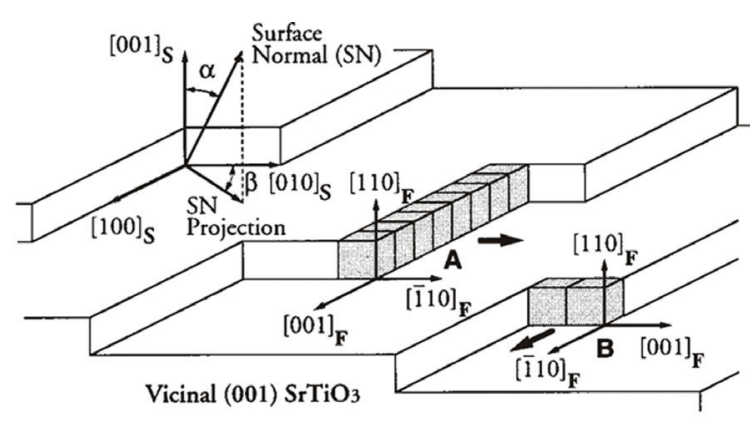

Fig. 7. STO (001) 표면의 형태 ${ }^{42)}$

박막의 압전 성능을 크게 감소시킨다.

휘발성이 강한 원소가 포함된 복합물을 증착하기 위해 서는 두 가지 방법이 있다. 첫 번째 방법은 증착 소스에 휘발성이 강한 원소를 원래 조성보다 더 많이 추가하는 방법이 있다. 즉, 휘발되는 양을 보상하기 위해 소스에 $\mathrm{PbO}$ 양을 5 15 wt\% 정도 더 증가시키는 방법이다. 두 번째 방법은 기판에서 최대한 휘발이 일어나는 것을 막는 것이다(Fig. 7.). 기상 증착 시 소스에서 이동된 원자들이 기판에 도달하면 소위 adatom 형태로 기판 표면을 따라 움직이다가 가장 안정한 원자간 결합이 일어나면 비로소 박막의 일부가 되어 증착이 이루어진다. 단결정 기판 표 면에서 step 이나 kink 사이트들은 dangling bond 수가 많기 때문에 쉽게 안정한 원자 결합을 이룰 수 있는 장소
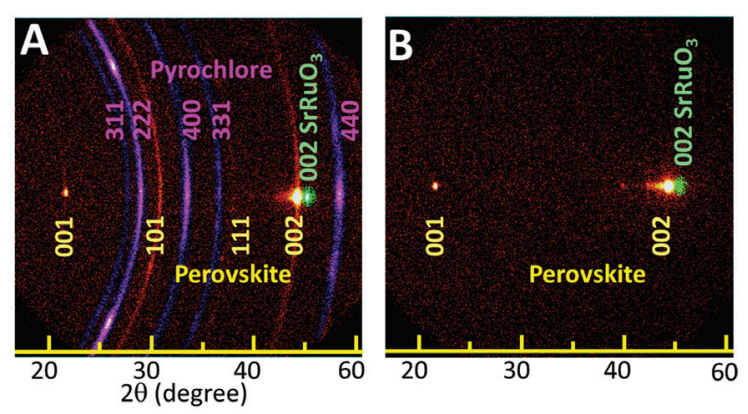

Fig. 8. PMN-PT 박막에 대한 기판의 miscut 효과. A. Si(001) 기판 에 증착한 경우. B. 4도 miscut한 Si 기판에 증착한 경우 ${ }^{39}$

이다. 반면, terrace는 dangling bond 수가 적기 때문에 평편한 표면 위에서는 쉽게 재증발이 일어날수 있다. 따 라서, 기판 표면의 step 및 kink 의 농도를 증가시키면 휘발성이 강한 원소들을 쉽게 붙잡아 둘 수 있다. miscut 기판을 사용하면 표면에 preferential nucleation site 가 증가하여 $\mathrm{PbO}$ 의 휘발을 억제하여 순수한 페로브스카 이트 상을 갖는 PMN-PT을 형성 할 수 있다는 것이 보 고된바 있다(Fig. 8.). ${ }^{39-42)}$

PZT 에 비해 매우 우수한 압전 성능을 갖고 있음에도 $\mathrm{PMN}-\mathrm{PT}$ 는 현재 매우 제한된 분야에만 적용되어 사용 되고 있다(Fig. 9.). PMN-PT의 가장 큰 약점은 고온성 능이 매우 떨어진다는 점이다. $\mathrm{PMN}-\mathrm{PT}$ 단결정은

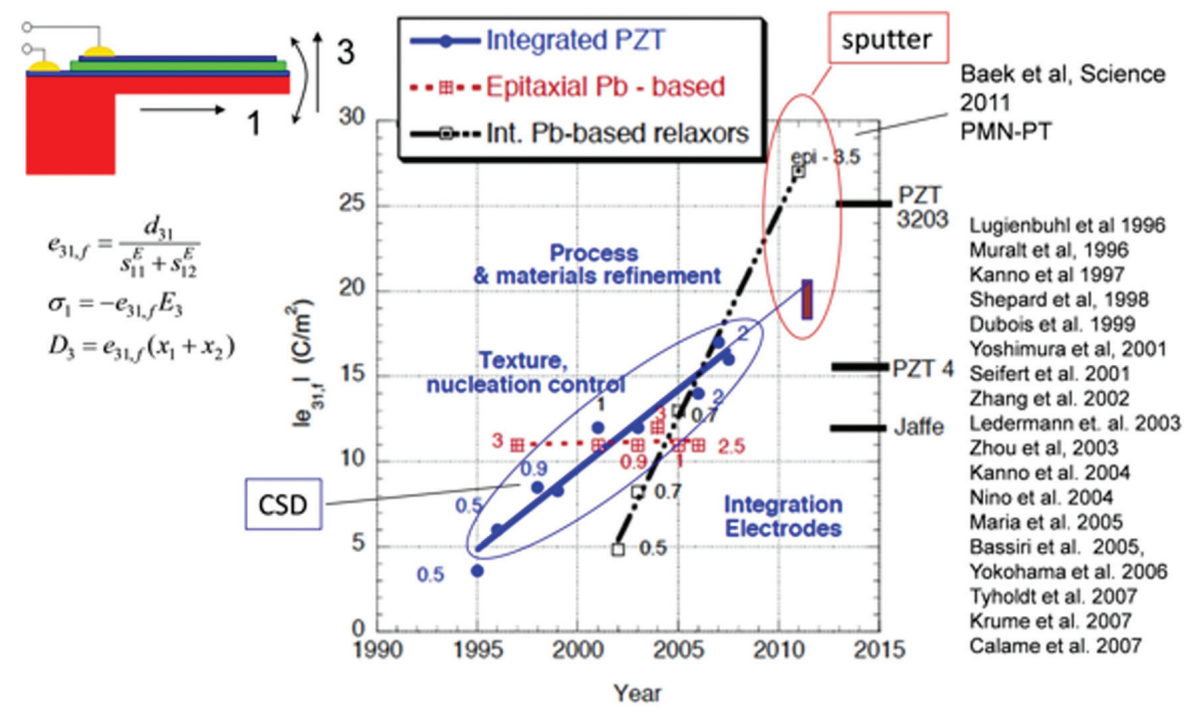

Fig. 9. 압전박막의 압전성능 비교 ${ }^{43}$ 


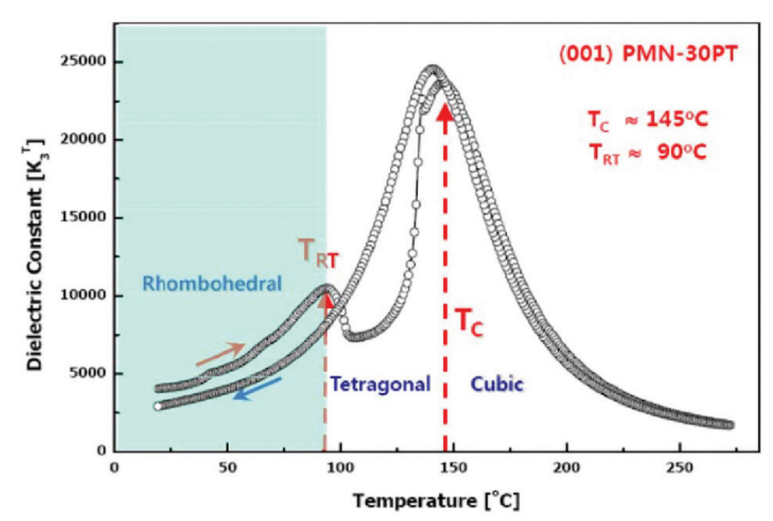

Fig. 10. 폴링된 (001) PMN-PT 단결정의 온도에 따른 유전율 변화 ${ }^{44)}$

PMN-rich 조성에서 rhombohedral 구조를 가질 때에 만 우수한 압전 성능을 보인다. PT-rich 조성의 tetragonal 구조에서는 압전 성능이 크게 떨어진다. 0.7PMN-0.3PT 단결정은 상온에서 rhombohedral 구 조를 갖는데 온도가 올라가면 약 90 도 부근에서 tetragonal 상으로, 140도 부근에서 cubic으로 상전이가 일어난다(Fig. 10.). 고온에서는 이러한 상전이 현상 때 문에 압전 성능이 매우 감소하여 실제로 $\mathrm{PMN}-\mathrm{PT}$ 를 사 용할 수 있는 온도범위는 상온에 한정된다. 이 때문에 의 료용 초음파 트랜스듀서 등 온도가 상온근처에서 유지될 수 있는 환경에서만 사용되어 왔다. PZT가 상대적으로
높은 상전이 온도를 갖고 있기 때문에 이는 PMN-PT 단 결정의 큰 단점으로 작용한다. ${ }^{2,30,44)}$

\subsection{3 $\mathrm{Pb}(\mathrm{Mg}, \mathrm{Nb}) \mathrm{O}_{3}-\mathrm{Pb}(\mathrm{Zr}, \mathrm{Ti}) \mathrm{O}_{3}$}

$\mathrm{PMN}-\mathrm{PT}$ 로 대표되는 완화형 강유전체 단결정의 우 수한 압전 성능이 1997년 발표된 이후 현재까지, 우수한 압전 성능을 유지하면서 고온 및 전기적 안정성을 향상시 키기 위한 노력이 계속되어 왔다. 이러한 발전과정에서 $\mathrm{Mn}$ : PMN-PZT 단결정이 현재 최신 버전의 압전 소재 이다. ${ }^{44-47)} \mathrm{PMN}-\mathrm{PZT}$ 단결정은 $\mathrm{T}_{\mathrm{RT}}$ 와 $\mathrm{Tc}$ 가 각각 140 도, 203 도이며 $d_{33}$ 가 $>1000(\mathrm{pC} / \mathrm{N})$ 이며, $\mathrm{k}$ 는 >0.9 이상의 값을 갖는 것으로 보고되었다. (Fig. 11.)

앞서 논의하였듯이 PZT 는 incongruent melting을 하기 때문에 용융공정을 포함한 단결정 성장 방법을 적용 할 수 없다. 이러한 문제를 해결하여 PMN-PZT 단결정 을 만들기 위해서 용융공정 없이 소결공정을 이용한 고상 단결정 성장법(solid-state single crystal growth, $\mathrm{SSCG}$ )이 개발되었다. ${ }^{30,48)}$ 파우더 안에 단결정 시드를 넣 고 “이차원 핵생성 및 성장”에 의한 결정립 성장이 일어 나는 환경을 조성하면 단결정 시드 표면에서만 결정 성장 이 일어나고 다른 파우더 내부에서는 성장이 일어나지 않 아 벌크 단결정을 얻을 수 있다. 웨어퍼 스케일의 큰 단결

\begin{tabular}{|c|c|c|c|c|c|c|c|c|c|c|}
\hline Materials & $\begin{array}{l}\mathrm{T}_{\mathrm{C}} \\
(\mathrm{C})\end{array}$ & $\begin{array}{l}\mathrm{T}_{\mathrm{ar}}{ }^{*} \\
(\mathrm{C})\end{array}$ & $\begin{array}{c}\mathrm{E}_{\mathrm{c}} \\
(\mathrm{kV} / \mathrm{cm})\end{array}$ & $\begin{array}{c}\mathrm{E}_{\mathrm{i}} \\
(\mathrm{kV} / \mathrm{cm})\end{array}$ & $\mathrm{K}_{\mathrm{d}}{ }^{\mathrm{T}}$ & $\begin{array}{c}\tan \delta \\
(\%)\end{array}$ & $\frac{\mathrm{d}_{31}}{(\mathrm{pC} / \mathrm{N})}$ & $k_{11}$ & $\mathrm{Q}_{\mathrm{n}}$ & $\begin{array}{l}\mathrm{FOM}^{* *} \\
(\mathrm{pC} / \mathrm{N})\end{array}$ \\
\hline $\begin{array}{l}\text { PZT-4 } \\
\text { Ceramics }\end{array}$ & 328 & 1 & 14.2 & 3.0 & 1,300 & 0.4 & 300 & 0.7 & 500 & $1.5 \times 10^{i}$ \\
\hline $\begin{array}{l}\text { PZT.8 } \\
\text { Ceramics }\end{array}$ & 300 & 1 & 18.7 & 7.0 & 1,000 & 0.4 & 230 & 0.64 & 1,000 & $2.3 \times 10^{i}$ \\
\hline $\begin{array}{l}\text { (001) PMN-PT } \\
\text { (Gen I) }\end{array}$ & 130 & 90 & 2.5 & 0 & 5,000 & 0.5 & 1,500 & 0.9 & 100 & $1.5 \times 10^{i}$ \\
\hline $\begin{array}{l}\text { (011) PMN-PT } \\
\text { (Gen I) }\end{array}$ & 130 & 90 & 2.5 & 0 & 3,500 & 0.4 & 1,100 & 0.88 & 200 & $2.2 \times 10^{i}$ \\
\hline $\begin{array}{l}\text { (001) PMN-PZT } \\
\text { (Gen II) }\end{array}$ & 211 & 144 & 4.5 & 0 & 4,500 & 0.5 & 1,400 & 0.9 & 150 & $2.1 \times 10^{i}$ \\
\hline $\begin{array}{l}\text { (011) PMN-PZT } \\
\text { (Gen II) }\end{array}$ & 211 & 144 & 5.0 & 0 & 3,000 & 0.4 & 1,100 & 0.88 & 200 & $2.2 \times 10^{i}$ \\
\hline $\begin{array}{l}\text { (001) PMN-PZT-Mn } \\
\text { (Gen III) }\end{array}$ & 203 & 145 & 6.0 & 1.0 & 3,400 & 0.2 & 1,100 & 0.9 & 1,000 & $1.1 \times 10^{6}$ \\
\hline $\begin{array}{l}\text { (011) PMN-PZT-Mn } \\
\text { (Gen III) }\end{array}$ & 203 & 145 & 7.0 & 1.0 & 2,500 & 0.2 & 850 & 0.88 & 1,250 & $1.1 \times 10^{6}$ \\
\hline
\end{tabular}

* Usage temperature range of ferroelectric ceramics is limited by $0.5 \mathrm{~T}_{\mathrm{C}}{ }^{81}$

** $\mathrm{FOM}=\mathrm{Q}_{\mathrm{m}} \cdot \mathrm{d}_{11}$

Fig. 11. 완화형 강유전체 단결정의 발전46) 
정을 만들기는 어렵지만 대신 작은 크기의 단결정 조각을 동시에 여러 개 만들 수 있어 생산단가를 낮출 수 있는 방 법이다. 또한 전통적인 용융공정으로 단결정을 제조할 경 우 잉곳의 위치에 따라 조성이 다른 문제가 항상 발생하 는데 고상단결정 성장법은 이러한 문제를 피할 수 있다. 단, 소결공정을 이용하기 때문에 $100 \%$ 밀도를 갖는 단결 정을 만들기는 어렵다는 단점이 있다.

본 물질을 단결정 박막으로 성장했다는 보고가 아직 존 재하지 않는다. 7 개의 원소를 갖고 있으며 pyrochlore 상 이 쉽게 형성될 가능성이 높기 때문에 에피택시 박막 성 장은 매우 도전적일 것으로 예상된다.

\subsection{4 우수한 압전성능의 소결체 압전소재}

최근 단결정이 아닌 소결체에서도 매우 우수한 압전 성 능이 나타날 수 있다고 보고 되었다. 첫 번째 예는 $\mathrm{Sm}$ : $\mathrm{PMN}-\mathrm{PT}$ 이다. ${ }^{49)}$ 금속이온 도핑을 이용하면 rhombohedral 과 tetragonal 결정구조 간 상변화에 필 요한 activation barrier를 크게 감소시킬 수 있고 결국 재료내부의 분극이 외부 전기장에 대해 훨씬 더 쉽게 회 전할 수 있게 되는 것이다. Activation barrier 가 충분 히 낮아져 거의 편평해지면 다결정 소결체내의 그레인들 이 랜덤한 방향으로 분포하고 있더라도 외부 전기장 방향 을 따라 반응하여 높은 압전 성질을 나타낼 수 있다는 것 이다.

앞서 논의 한 것처럼 완화형 강유전체는 단결정일 때와 소결체일 때의 압전 성능차이가 매우 심하다. $\mathrm{PMN}-\mathrm{PT}$ 의 경우 단결정은 $\mathrm{d}_{33}$ 값이 $>2,000(\mathrm{pC} / \mathrm{N})$ 인데 반해 소 결체는 $\langle 500(\mathrm{pC} / \mathrm{N})$ 정도 밖에 되지 않는다. 그러나, 희 토류 원소에 속하는 $\mathrm{Sm}$ 을 도핑하면 소결체라도 1,500 $\mathrm{pC} / \mathrm{N}$ 이라는 매우 높은 압전 성능을 보일 수 있다. 이러 한 성질은 박막 증착 공정 측면에서 매우 큰 돌파구를 제 시한다. 단결정 박막은 매우 까다로운 공정 조건하에서만 성장이 가능하며, 공정 윈도우가 좁기 때문에 재현성에 문제가 발생할 가능성이 크다. 다결정 박막은 공정 윈도 우가 매우 넓고, 버퍼층이 필요 없으며, 하부전극을 일반 금속을 사용할 수 있기 때문에 $\mathrm{Sm}: \mathrm{PMN}-\mathrm{PT}$ 소재를 사 용하면 증착에 대한 부담을 상당히 덜 수 있다. 다만,
$\mathrm{Sm}$ : PMN-PT 소재의 Tc가 약 89도로 매우 낮아 기존 $\mathrm{PMN}-\mathrm{PT}$ 단결정이 갖고 있는 고온 안정성 문제를 그대 로 갖고 있다는 것이 단점이 될 수 있다.

두 번째 예는 $\mathrm{BiFeO}_{3}-\mathrm{PbTiO}_{3}-\mathrm{LaFeO}_{3}$ 솔리드 솔루션 이다. ${ }^{50)} \mathrm{BiFeO}_{3}-\mathrm{PbTiO}_{3}$ tetragonality 가 매우 커서 $\mathrm{c}-$ 와 a-도메인 사이의 형성되는 스트레인 $(\sim 0.18)$ 이 $\mathrm{PbTiO}_{3}(\sim 0.06)$ 나 $\mathrm{BiFeO}_{3}(\sim 0.01)$ 보다 훨씬 크다. 이 와 같이 매우 큰 스트레인이 존재하는 매트릭스에 $\mathrm{La}$ 도 핑을 하면 도메인 사이즈가 크게 감소한다. 이 경우 외부 전기장에 의해 non- $180^{\circ}$ 도메인 스위칭이 일어나면서 다결정 소결체에서도 매우 큰 스트레인을 얻을 수 있다는 것이다. $\mathrm{BiFeO}_{3}-\mathrm{PbTiO}_{3}-\mathrm{LaFeO}_{3}$ 소결체의 경우 $1.2 \%$ 의 매우 큰 스트레인을 전기장으로 유도시킬 수 있다. 이 소결체의 조성을 탐색하여 최고 $1,600 \mathrm{pm} / \mathrm{V}$ 수준의 $\mathrm{d}_{33}$ 값이 보고되었지만 $\mathrm{k}$ 값은 아직 보고되지 않았다.

이와 같이 다결정 소결체임에도 단결정에 준하는 높은 압전 성능을 갖는 소재를 이용하여 $\mathrm{p}-\mathrm{MUT}$ 소자를 제작 하는 것은 공정단가를 줄이고, 생산성을 향상시키는 동시 에 소자의 성능을 향상시킬 수 있는 돌파구가 될 수 있을 것이라 예상된다. 위 컨셉이 박막에서도 잘 적용되는지 앞으로 지속적인 연구가 필요하겠다.

\subsection{5 소재 성능 제어 기구}

압전 박막은 기판 위에 증착되기 때문에 격자상수와 열 팽창계수 차이 때문에 misfit strain 및 thermal strain 이 존재한다. 2 차원 구조의 박막 특성상 bi-axial strain 을 받게 된다. 압전 성능은 소재의 결정 구조와 도메인 구 조에 민감하게 변하기 때문에 박막에 존재하는 스트레인 은 압전 성능을 변화시킬 수 있는 변수가 된다. 이는 스트 레인이라는 벌크에는 적용할 수 없는 새로운 변수를 이용 하여 압전 물성을 제어할 수 있다는 점에서 장점이 될 수 있지만, 벌크 단결정을 통해 얻어진 지식이 박막에 곧바 로 적용하기 어렵고, 압전 박막의 성능을 예측하기 힘들 다는 점에서 단점이 될 수 있다. ${ }^{39,51-53)}$

$\mathrm{PMN}-\mathrm{PT}$ 혹은 PZT 처럼 결정 구조가 다른 두 가지 모 물질이 솔리드 솔루션을 이룰 때 상태도에서 온도에 거의 영향이 없이 수직으로 형성된 morphotropic phase 


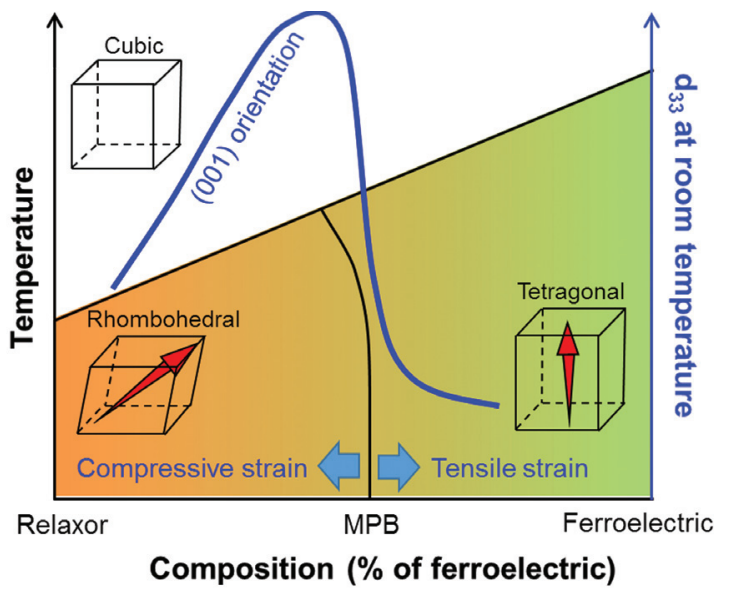

Fig. 12. 완화형 강유전체 상태도 모식도 및 스트레인에 따른 MPB 이동 ${ }^{40)}$

boundary(MPB)가 존재한다. (Fig. 12.) 일반적으로 압 전 성능은 $\mathrm{MPB}$ 부근 rhombohedral 영역의 조성에서 최 대가 된다. 벌크 단결정일 경우 $\mathrm{MPB}$ 의 위치는 조성에 의 해 결정되지만 박막일 경우 스트레인에 따라 바뀔 수 있 다. 기판과의 격자상수 차이에 따라 biaxial compressive 와 tensile 스트레인을 제어할 수 있고 이에 따라 각각 tetragonal과 rhombohedral 결정 구조가 안정한 것으 로 보고 되었다. 즉, biaxial tensile 경우 $\mathrm{MPB}$ 는 오른 쪽으로 이동하며, biaxial compressive 인 경우 왼쪽으 로 이동한다. ${ }^{30,39)}$

$\mathrm{PMN}-\mathrm{PT}$ 박막이 실리콘 기판 위에 증착되었을 경우 격자상수차이에 의한 스트레인보다는 열팽창계수 차이 에 의한 스트레인이 더 우세하게 작용한다. PMN-PT 보
다 $\mathrm{Si}$ 의 열팽창계수가 작기 때문에 고온에서 $\mathrm{PMN}-\mathrm{PT}$ 증착 후 상온까지 식히는 동안 PMN-PT 는 biaxial tensile 스트레인을 받게 된다. 따라서, 실리콘 기판 위에 소자를 제작할 경우 열스트레인을 고려하여 최적 조성을 선택해야 한다.

임프린트(imprint)는 분극-전기장 곡선(P-E curve) 에서 hysteresis loop 이 중앙에서 벗어나 왼쪽 또는 오 른쪽으로 이동되어 나타나는 현상을 말한다(Fig. 13.). 이는 박막 내부에 built-in voltage 가 있음을 뜻하는 것 으로 박막에서 특히 자주 일어난다. 원인으로는 박막 내 부의 금속이온-산소 결함쌍이나, 박막과 금속 전극간의 dead layer 형성 등 몇 가지 시나리오가 제시되었다. 임 프린트 현상은 압전 응용시 매우 큰 장점으로 작용한다. 첫째, 소자의 전압 안정성을 향상시킨다. 압전 박막에서 의 분극 방향은 주어진 외부 전기장에 대해 소자가 움직 일 수 있는 방향을 결정한다. 즉, 압전 박막의 분극 방향 이 바뀌게 되면 소자는 이전과 반대방향으로 작동하게 된 다. 이는 소자의 신뢰성과 관계되는 심각한 문제다. 이를 해결하기 위해 벌크 단결정 연구자들은 $\mathrm{Mn}$ 원소 등을 도 핑하여 coercive field를 향상 시키는 방향으로 많은 노력 이 이루어져 왔다. 박막에 존재하는 임프린트는 별도의 도핑공정 없이 분극 스위칭을 억제하는 역할을 할 수 있 다. 둘째, 폴링 공정을 생략할 수 있다. 다결정 박막이나 임프린트가 나타나지 않는 박막일 경우 압전 성능 향상을 위해 소재내의 분극을 한쪽 방향으로 정렬시키는 폴링 과 정이 반드시 필요하다. 높은 온도에서 높은 전기장을 가 해 이루어지는 폴링 공정이 생략되면 생산 공정을 단순화
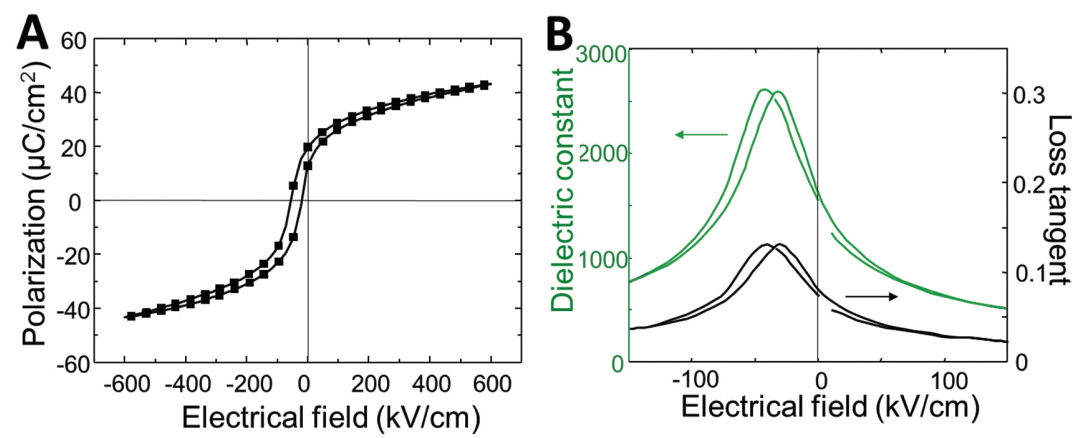

Fig. 13. A. P-E curve, B. Si에 증착한 단결정 PMN-PT 박막의 유전상수 
할 수 있다는 장점이 있다. 셋째, 초음파 트랜스듀서나 센 서로 사용할 경우 센싱 성능을 향상 시킬 수 있다. 임프린 트 현상은 압전 박막의 유전율을 감소시키는 역할을 하 고, 센싱 성능지수 $\left(\mathrm{e}_{31} / \varepsilon_{\mathrm{r}}\right)$ 를 증가시킨다. ${ }^{39,54,55)}$

\section{3. 결론 및 전망}

고성능 마이크로 트랜스듀서가 상용화된다면 현재 포 화상태에 빠져있는 압전 관련 연구 및 시장을 활성화 시 킬 뿐 아니라, 모바일 전자소자와 결합하여 엄청나게 큰 파급효과를 가져올 것으로 예상된다. 예를 들어, 핸드폰 에 적용 가능한 저전력 소형 초음파 트랜스듀서를 개발 하면, 지문이나 지정맥 인식이 가능해져 기존 정전식 지 문인식이나 홍채 및 얼굴인식과 같은 기술에 비해 보안 성을 획기적으로 향상 시킬 수 있다. 또한 3차원 이미징 이 가능한 소형 초음파 의료기기, 드론과 같은 자율주행 체의 거리감지 및 충돌방지 센서, 촉감증강 가상현실, 초 음파 뇌 자극을 이용한 마비 치료, 근거리 정보통신 등이 가능해져 미래 사회는 새로운 전기를 맞게 될 것으로 기 대된다.

그러나, 이를 위해서는 아직 많은 과제가 남아있다. 마 이크로 트랜스듀서 제작 공정에서 가장 어려운 부분은 역 시 고성능의 압전 박막을 성장시키는 공정이다. 산업체에 적용할 수 있고, 대면적화가 가능하고, 생산속도, 불량 률, 수율을 고려하여 경제성이 확보될 수 있는 증착 공정 개발이 필요하다. 제 1 세대 압전 단결정인 $\mathrm{PMN}-\mathrm{PT}$ 의 단점을 해결하기 위해 개발된 최신 버전의 완화형 강유전 체는 $\mathrm{Mn}$ : $\mathrm{PMN}-\mathrm{PZT}$ 로 총 7 개의 원소로 이루어져 있 다. 앞으로 소재 개발은 조성이 복잡해지고 더 많은 원소 와 도펀트를 포함하게 될 것으로 예상된다. 이렇게 복잡 하고 다양한 원소를 포함하고 있는 물질을 단결정 박막으 로 합성할 수 있는 증착 기술을 개발하는 것이 절실히 필 요하다. 실험실 수준에서뿐만 아니라 산업체 적용이 용이 하도록 최대한 넓은 공정 윈도우를 확보할 수 있도록 공 정 조건 탐색이 필요하다. 에피택시 박막 증착을 가능케 하는 실리콘 기판위 버퍼층에 대한 연구도 필요하다. 산 업체에서 생산이 가능할 것으로 보이는 $\mathrm{CeO}_{2} / \mathrm{YSZ}$ 버퍼
층이 있지만 $\mathrm{FWHM}$ 이 $\sim 0.7^{\circ}$ 수준으로 결정성이 좋지 않다. 결정성을 FWHM $<0.1^{\circ}$ 로 향상시킬 수 있는 공정 개발이나 새로운 버퍼층을 개발하려는 노력이 필요하다. 이와 관련하여 에피택시 전사 기술도 관심을 기울일 필요 가 있다. 동일한 페브스카이트 구조를 갖는 단결정 기판 위에서 압전 박막을 성장시킨 후 $\mathrm{Si}$ 기판으로 전사하면 버퍼층의 낮은 결정성 문제를 해결할 수 있을 것이다.

이러한 노력과 더불어, 최근 발표된 우수한 압전 성능 을 갖는 다결정 소결체 소재에 대한 박막화 연구도 함께 이루어져야 하겠다. 마지막으로 본 리뷰논문에는 다루지 않았지만, 날이 갈수록 중요해 지는 환경문제에 대응하기 위해 무연(lead-free)계 압전 박막에 대한 연구도 반드시 필요하다.

\section{참고문헌}

1. Qiu, Y., Gigliotti, J., Wallace, M., Griggio, F., Demore, C., Cochran, S., Trolier-McKinstry, S. "Piezoelectric micromachined ultrasound transducer (PMUT) arrays for integrated sensing, actuation and imaging." Sensors, 15 [4], 8020-8041 (2015)

2. Zhang, S., Li, F., Jiang, X., Kim, J., Luo, J., Geng, $\mathrm{X}$. "Advantages and challenges of relaxor-PbTiO3 ferroelectric crystalsforelectroacoustictransducers - A review." Progress in materials science, 68, 1-66 (2015)

3. Mulyono, D., Jinn, H. S. "A study of finger vein biometric for personal identification." pp. 1-8 In 2008 International Symposium on Biometrics and Security Technologies. IEEE. (2008)

4. Jiang, X., Kim, J., Kim, K. "Relaxor-PT single crystal piezoelectric sensors." Crystals, 4 [3], 351-376 (2014)

5. Jung, J., Lee, W., Kang, W., Shin, E., Ryu, J., Choi, $\mathrm{H}$. "Review of piezoelectric micromachined ultrasonic transducers and their applications." Journal of Micromechanics and Microengineering, 27 [11], 113001 (2017)

6. Muralt, P., J. Baborowski. "Micromachined ultrasonic transducers and acoustic sensors based on piezoelectric thin films." Journal of electroceramics 12 [1-2], 101108 (2004)

7. Dausch, D. E., Castellucci, J. B., Chou, D. R., Von Ramm, O. T. "Theory and operation of 2-D array piezoelectric micromachined ultrasound transducers." 
ieee transactions on ultrasonics, ferroelectrics, and frequency control 55 [11], 2484-2492 (2008)

8. Hajati, A., Latev, D., Gardner, D., Hajati, A., Imai, D., Torrey, M., Schoeppler, M. "Three-dimensional micro electromechanical system piezoelectric ultrasound transducer." Applied Physics Letters 101 [25], 253101 (2012)

9. Dausch, D. E., Gilchrist, K. H., Carlson, J. B., Hall, S. D., Castellucci, J. B., von Ramm, O. T. "In vivo real-time 3-D intracardiac echo using PMUT arrays." IEEE transactions on ultrasonics, ferroelectrics, and frequency control 61 [10], 1754-1764 (2014)

10. Hong, E., Trolier-McKinstry, S., Smith, R., Krishnaswamy, S. V., Freidhoff, C. B. "Vibration of micromachined circular piezoelectric diaphragms." IEEE transactions on ultrasonics, ferroelectrics, and frequency control 53 [4], 697-706 (2006)

11. Klee, M., Mauczok, R., van Heesch, C., Boots, H., de Wild, M., op het Veld, B., Meczko, M. "Piezoelectric thin film platform for ultrasound transducer arrays." pp. 196-199, 2011 IEEE International Ultrasonics Symposium. IEEE, 2011.

12. Klee, M., Boots, H., Kumar, B., Van Heesch, C., Mauczok, R., Keur, W., Van Leuken, L. "Ferroelectric and piezoelectric thin films and their applications for integrated capacitors, piezoelectric ultrasound transducers and piezoelectric switches." IOP Conference Series: Materials Science and Engineering. Vol. 8. No. 1. IOP Publishing, 2010.

13. Shelton, S., Chan, M. L., Park, H., Horsley, D., Boser, B., Izyumin, I., ... \& Sammoura, F. "CMOScompatible AlN piezoelectric micromachined ultrasonic transducers." pp. 402-405, 2009 ieee international ultrasonics symposium. IEEE, 2009.

14. Jung, J., Kim, S., Lee, W., Choi, H. "Fabrication of a two-dimensional piezoelectric micromachined ultrasonic transducer array using a top-crossoverto-bottom structure and metal bridge connections." Journal of Micromechanics and Microengineering 23 [12], 125037 (2013)

15. Mo, J. H., Fowlkes, J. B., Robinson, A. L., Carson, P. L. "Crosstalk reduction with a micromachined diaphragm structure for integrated ultrasound transducer arrays." IEEE transactions on ultrasonics, ferroelectrics, and frequency control 39 [1], 48-53 (1992)

16. Gong, D., Cai, H., Xia, Y., Ma, S., Liu, H., Chiu, Y., Jin, Y. "Fabrication and characterization of AlN based
Piezoelectric Micromachined Ultrasonic Transducer for contact sensing." pp. 1442-1447, In 2018 19th International Conference on Electronic Packaging Technology (ICEPT). IEEE. (2018)

17. Percin, G., Khuri-Yakub, B. T. "Micromachined 2-D array piezoelectrically actuated flextensional transducers." 1997 IEEE Ultrasonics Symposium Proceedings. An International Symposium (Cat. No. 97CH36118). Vol. 2, pp. 959-962, IEEE, (1997)

18. Trolier-McKinstry, S., Muralt, P. "Thin film piezoelectrics for MEMS. Journal of Electroceramics." 12 [1-2], 7-17 (2004)

19. Muralt, P. "PZT thin films for microsensors and actuators: Where do we stand?" IEEE transactions on ultrasonics, ferroelectrics, and frequency control, 47 [4], 903-915 (2000)

20. Wang, S. J., Ong, C. K., You, L. P., \& Xu, S. Y. "Epitaxial growth of yittria-stabilized zirconia oxide thin film on natively oxidized silicon wafer without an amorphous layer." Semiconductor science and technology 15 [8], 836 (2000)

21. Fork, D. K., Fenner, D. B., Connell, G. A. N., Phillips, J. M., \& Geballe, T. H. "Epitaxial yttria-stabilized zirconia on hydrogen-terminated Si by pulsed laser deposition." Applied physics letters, 57 [11], 1137-1139 (1990)

22. Wang, S. J., Ong, C. K., Xu, S. Y., Chen, P., Tjiu, W. C., Huan, A. C. H., Choi, W. K. "Electrical properties of crystalline YSZ films on silicon as alternative gate dielectrics." Semiconductor science and technology, 16 [3], L13 (2001)

23. Nguyen, M. D., Nazeer, H., Karakaya, K., Pham, S. V., Steenwelle, R., Dekkers, M., Rijnders, G. "Characterization of epitaxial $\mathrm{Pb}(\mathrm{Zr}, \mathrm{Ti}) \mathrm{O}_{3}$ thin films deposited by pulsed laser deposition on silicon cantilevers." Journal of micromechanics and microengineering, 20 [8], 085022 (2010)

24. de Coux, P., Bachelet, R., Gatel, C., Warot-Fonrose, B., Fontcuberta, J., Sánchez, F. "Mechanisms of epitaxy and defects at the interface in ultrathin YSZ films on Si (001)." CrystEngComm, 14 [23], 78517855 (2012)

25. Singamaneni, S.R., Prater, J.T., Narayan, J., "Multifunctional epitaxial systems on silicon substrates." Appl. Phys. Rev. 3, 031301 (2016)

26. Reiner, J. W., Kolpak, A. M., Segal, Y., Garrity, K. F., Ismail-Beigi, S., Ahn, C. H., Walker, F. J. "Crystalline oxides on silicon." Advanced Materials, 


\section{2 [26-27], 2919-2938 (2010)}

27. Dekkers, M., Nguyen, M. D., Steenwelle, R., te Riele, P. M., Blank, D. H., Rijnders, G. "Ferroelectric properties of epitaxial $\mathrm{Pb}(\mathrm{Zr}, \mathrm{Ti}) \mathrm{O}_{3}$ thin films on silicon by control of crystal orientation." Applied physics letters, 95 [1], 012902 (2009)

28. Zhou, Z., Yoshida, S., Tanaka, S. "Epitaxial PMnN$\mathrm{PZT} / \mathrm{Si}$ MEMS ultrasonic rangefinder with $2 \mathrm{~m}$ range at $1 \mathrm{~V}$ drive." Sensors and Actuators A: Physical, 266, 352-360 (2017)

29. Funakubo, H., Dekkers, M., Sambri, A., Gariglio, S., Shklyarevskiy, I., Rijnders, G. "Epitaxial PZT films for MEMS printing applications." MRS bulletin, 37 [11], 1030-1038 (2012)

30. Zhang, S., Li, F. "High performance ferroelectric relaxor- $-\mathrm{PbTiO}_{3}$ single crystals: Status and perspective." Journal of Applied Physics, 111 [3], 2 (2012)

31. Jaffe, B., R. S. Roth, S. Marzullo. "Piezoelectric properties of lead zirconate-lead titanate solidsolution ceramics." Journal of Applied Physics 25 [6], 809-810 (1954)

32. Haertling, Gene H. "Ferroelectric ceramics: history and technology." Journal of the American Ceramic Society 82 [4], 797-818 (1999)

33. Berlincourt, D. A., C. Cmolik, and H. Jaffe. "Piezoelectric properties of polycrystalline lead titanate zirconate compositions." Proceedings of the IRE 48 [2], 220-229 (1960)

34. Lou, X., Hu, X., Zhang, M., Morrison, F. D., Redfern, S. A. T., Scott, J. F. "Phase separation in lead zirconate titanate and bismuth titanate during electrical shorting and fatigue." Journal of applied physics 99 [4], 044101 (2006)

35. Park, S. E., \& Shrout, T. R. "Ultrahigh strain and piezoelectric behavior in relaxor based ferroelectric single crystals." Journal of Applied Physics, 82 [4], 1804-1811 (1997)

36. Sun, E., Cao, W. "Relaxor-based ferroelectric single crystals: Growth, domain engineering, characterization and applications. Progress in materials science, 65, 124-210 (2014)

37. Hurle, D. T. "Mechanisms of growth of metal single crystals from the melt." Progress in Materials Science, 10 81-IN15. (1963)

38. Zawilski, K. T., DeMattei, R. C., Feigelson, R. S. "Zone leveling of lead magnesium niobate-lead titanate crystals using RF heating." Journal of crystal growth, 277 [1-4], 393-400 (2005)

39. Baek, S. H., Park, J., Kim, D. M., Aksyuk, V., Bu, S. D., Das, R. R., Felker, D. A., Lettieri, J., Vaithyanathan, V., Bassiri-Gharb, N., Bharadwaja, S. S. N., Chen, Y. B., Sun, H. P., Jang, H. W., Kreft, D. J., Nagarajan, V., Streiffer S. K., Ramesh, R., Pan, X. Q., Trolier-McKinstry, S., Schlom, D. G., Rzchowski, M. S., Blick, R., Eom, C. B. "Giant piezoelectricity on $\mathrm{Si}$ for hyper-active MEMS." Science 334, 958 (2011)

40. Baek, S. H., Rzchowski, M. S., Aksyuk, V. A. “Giant piezoelectricity in PMN-PT thin films: Beyond PZT." MRS Bull. 37, 1022 (2012)

41. Baek, S. H., Eom, C. B. Epitaxial integration of perovskite-based multifunctional oxides on silicon. Acta Mater. 61, 2734-2750 (2013)

42. Koster, G., Klein, L., Siemons, W., Rijnders, G., Dodge, J. S., Eom, C. B., Blank, D. H. A., Beasley, M. R. "Structure, physical properties, and applications of $\mathrm{SrRuO}_{3}$ thin films." Reviews of Modern Physics, 84 [1], 253 (2012)

43. The improvement of piezoelectricity in PZT and related thin films after Paul Muralt, See https:// www.petmem.eu/the-technology/processingtechnology/piezoelectric-materials/

44. Lee, H. Y., "Development and application of highly efficient piezoelectric single crystals.(in Korean)" Ceramist, 17 [2], 7-14 (2014)

45. Zhang, S., Lee, S. M., Kim, D. H., Lee, H. Y., Shrout, T. R. "Characterization of $\mathrm{Mn}$-modified $\mathrm{Pb}\left(\mathrm{Mg}_{1 / 3} \mathrm{Nb}_{2 / 3}\right)$ $\mathrm{O}_{3}-\mathrm{PbZrO}_{3}-\mathrm{PbTiO}_{3}$ single crystals for high power broad bandwidth transducers." Appl. Phys. Lett. 93, 122908 (2008)

46. Oh, H. T., Lee, J. Y., Lee, H. Y. "Mn-modified PMN-PZT $\left[\mathrm{Pb}\left(\mathrm{Mg}_{1 / 3} \mathrm{Nb}_{2 / 3}\right) \mathrm{O}_{3}-\mathrm{Pb}\left(\mathrm{Zr}\right.\right.$, Ti) $\left.\mathrm{O}_{3}\right]$ single crystals for high power piezoelectric transducers." Journal of the Korean Ceramic Society, 54 [2], 150157. (2017)

47. Yan, Yongke, Kyung-Hoon Cho, Shashank Priya. "Piezoelectric properties and temperature stability of $\mathrm{Mn}$-doped $\mathrm{Pb}\left(\mathrm{Mg}_{1 / 3} \mathrm{Nb}_{2 / 3}\right)-\mathrm{PbZrO}_{3}-\mathrm{PbTiO}_{3}$ textured ceramics." Applied Physics Letters, 100 [13], (2012)

48. Lee, H. Y. "Development of high-performance piezoelectric single crystals by using solid-state single crystal growth (SSCG) method." Handbook of Advanced Dielectric, Piezoelectric and Ferroelectric Materials. Woodhead Publishing, 158-172. (2008)

49. Li, F., Lin, D., Chen, Z., Cheng, Z., Wang, J., Li, C., 
Xu, Z., Huang, Q., Liao, X., Chen, L.Q. Shrout, T.R., Zhang, S. "Ultrahigh piezoelectricity in ferroelectric ceramics by design." Nature materials, 17 [4], 349 (2018)

50. Singh, A., Chatterjee, R. "Multiferroic Properties of $\mathrm{La}-\mathrm{Rich} \quad \mathrm{BiFeO}_{3}-\mathrm{PbTiO}_{3} \quad$ Solid Solutions." Ferroelectrics, 433 [1], 180-189 (2012)

51. Schlom, D.G., Chen, L.Q., Fennie, C.J., Gopalan, V., Muller, D.A., Pan, X., Ramesh, R., Uecker, R. "Elastic strain engineering of ferroic oxides." MRS bull. 39, 118 (2014)

52. Nagarajan, V., Roytburd, A., Stanishevsky, A., Prasertchoung, S., Zhao, T., Chen, L., Melngailis, J., Auciello, O., Ramesh, R., "Dynamics of ferroelastic domains in ferroelectric thin films." Nat. Mater. 2, 43 (2003)

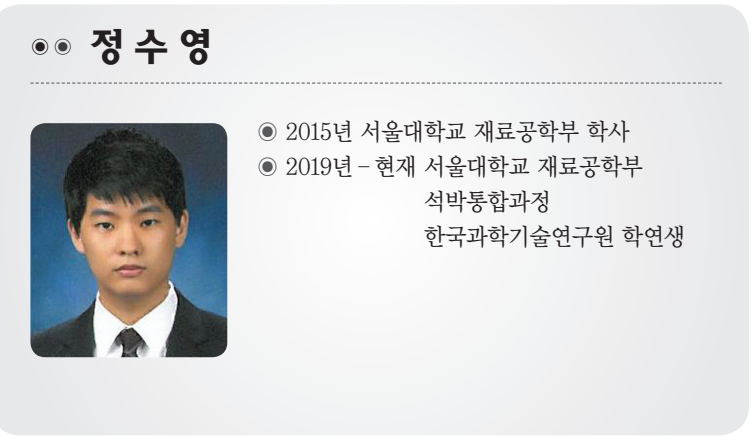

53. Zhang, J. X., Schlom, D. G., Chen, L. Q., Eom, C. B. "Tuning the remanent polarization of epitaxial ferroelectric thin films with strain." Applied Physics Letters, 95 [12], 122904 (2009)

54. Gruverman, A., Rodriguez, B.J., Kingon, A.I., Nemanich, R.J., Tagantsev, A.K., Cross, J.S. Tsukada, M. "Mechanical stress effect on imprint behavior of integrated ferroelectric capacitors." Applied Physics Letters, 83 [4], 728-730 (2003)

55. Zhou, Y., Chan, H. K., Lam, C. H., Shin, F. G. "Mechanisms of imprint effect on ferroelectric thin films." Journal of applied physics, 98 [2], 024111 (2005)

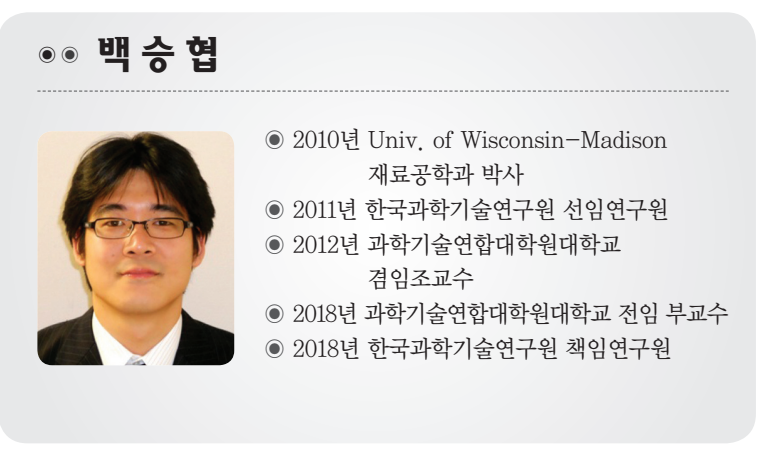

